\title{
Social Capital and Academic Research Performance: A Conceptual Model Proposal
}

\author{
Fernando Martín-Alcázar ${ }^{1}$, Marta Ruiz-Martinez ${ }^{1}$ \& Gonzalo Sánchez-Gardey ${ }^{1}$ \\ ${ }^{1}$ University of Cadiz, Spain \\ Correspondence: Marta Ruiz-Martinez, University of Cadiz, Spain.
}

Received: December 30, 2018

Accepted: January 25, 2019

Online Published: January 30, 2019

doi:10.5430/ijba.v10n2p22

URL: https://doi.org/10.5430/ijba.v10n2p22

\begin{abstract}
It is increasingly important for the academic community to know how social capital of research group members is building; higher levels of social capital could lead to researchers to have a higher number of publications and to improve the quality of these publications. Having a greater knowledge of the role of the different dimensions of social interactions in building internal and external social capital could help to improve the social capital of research groups. This paper offers a conceptual model in which the relationship between social capital embedded in research networks and the performance of researchers is established. To build the proposed model, this paper reviews of the major literature on social capital, drawing on previous theoretical approaches and the existing empirical evidence on the social capital construct and its effects.
\end{abstract}

Keywords: social capital, academia research, performance

\section{Introduction}

Nowadays, knowledge is considered a fundamental driver of the economic growth and development of countries as well as of the performance of organizations (Chatterton \& Goddard, 2000; Huggins \& Johnston, 2009). In knowledge-based economies, the knowledge is generated by diverse agents (such as universities, research centres and companies) and transferred and acquired by other organizations that use it together with the other productive factors for their economic activity.

Universities have traditionally had the missions of carrying out teaching and research activities. But in recent years, universities have experienced important changes in their environment; there exist a greater social demand for transferring their research results to society (Etzkowitz et al. 2000; Rothaermel, Agung \& Jiang, 2007). In this context, the generation and management of scientific and technological knowledge produced by universities are relevant and justify the growing interest for knowing the potential of universities' intellectual capital in relation to their research results (Leitner, 2004; Sánchez, Elena \& Castrillo, 2009).

Many scholars use the term intellectual capital to refer to all knowledge that can be used by organizations to obtain competitive advantages (Nahapiet \& Ghoshal, 1998; Youndt, Subramaniam, \& Snell, 2004). Although some authors point out several elements of intellectual capital (Bontis, 1996; Edvinson \& Malone, 1997; Steward, 1997), it seems that there is a certain consensus in considering that intellectual capital is formed by human capital, organizational capital and social capital of organizations (Youndt et al., 2004). Human capital refers to the knowledge and skills of employees, organizational capital is constituted by the institutionalized knowledge that the organization possesses and social capital represents knowledge within groups and networks of personal relationships (Youndt, Subramaniam, \& Snell, 2004).

Regarding the latter, the concept of social capital has been analysed mainly from two different perspectives. On the one hand, it has been considered as an individual good, which can be used to obtain personal advantages and, on the other hand, as a collective good that cannot be possessed by an individual (Portes, 1998). Bourdieu (1985) considers that individual social capital is established by the resources that the individual possesses that become available to others through social relationships (Portes, 1998; Rostila, 2010). In this line, Kostova and Roth (2003) point out that social capital is a private good that mainly benefits the actors that possess it. However, some authors criticize the inappropriateness of calling individual social capital because it is inserted in networks of relationships, although the benefits may be exclusive and used to achieve individual objectives (Rostila, 2010). 
In the last two decades an important body of theoretical and empirical literature has emerged focused on the study of the social capital of organizations and influencing research in areas such as knowledge management, among others (Kwon \& Adler, 2014). Indeed, knowledge management literature has emphasized the role of social capital as barriers and facilitators of knowledge management processes. Social capital internal to groups or organizations has been recognised as both barriers and facilitators of acquisition, creation, sharing and transfer knowledge management processes (Pinho, Rego \& Pina e Cunha, 2012). Similarly, external social capital related to participate in networks and cooperate with other groups or organizations has been also identified as barriers and facilitators of the four knowledge management processes (Pinho, Rego \& Pina e Cunha, 2012).

The organizational and management literature includes numerous empirical studies that analyse the effects of social capital on the results of organizations. In these works, social capital is used as an instrumental variable to explain various returns within organizations. Several studies at the individual level establish the relationship between social capital and compensation (Carroll \& Teo, 1996), or its effect on improvements in the professional careers of employees (Xiao \& Tsui, 2007; Rodan, 2010; Bolander et al., 2015) analysing the mechanisms that explain why social capital affects results (Seibert, Kraimer \& Liden, 2001). Other studies focus on analysing the effects of social capital on the acquisition and exchange of information and knowledge (Anderson, 2008; Van den Hooff \& Huysman 2009; Hau et al., 2013; Chang, Hsu \& Lee, 2015; Jiang \& Hu, 2015; Choi, 2015).

There are numerous studies that, using the organization as a unit of analysis, examine the relationship between social capital and diverse economic measures such as market expansion, improvements in sales or business profits (Park \& Luo, 2001; Yiu \& Lau, 2008; Andrews, 2010); the survival of companies (Fischer \& Pollock, 2004; Kalnins \& Chung, 2006); innovation (Chen, Chang, \& Hung, 2008, De Clercq, Thongpapanl \& Dimov, 2011, Delgado-Verde et al., 2011, Pérez-Luño et al., 2011); income and sales technology companies (Collins \& Smith, 2006); the results of public organizations (Andrews, 2010) and start-ups companies (Maurer \& Ebers, 2006; Pirolo, \& Presutti, 2010), among others.

Much of the existing empirical evidence on the relationship between social capital and the performance of organizations finds a positive relationship between both variables. However, some studies offer contradictory results to the previous ones, showing in some cases evidence of the existence of a negative relationship between both variables (Malik, 2012; Rouzies \& Hulland, 2014) or with an inverted U form in others (Yu \& Chiu, 2010; Villena, Revilla \& Choi, 2011).

As mentioned previously, universities are knowledge producers. Currently, an important part of scientific production is the result of scientific collaboration between researchers or research groups embedded in research networks (Bozeman, Fay, \& Slade, 2013; Cummings \& Kiesler, 2014). Several papers have pointed out the significant role of scientific collaboration for research productivity (Katz \& Martin, 1997; Lee \& Bozeman, 2005) and research impact (Gazni \& Didegah, 2011; Sooryamoorthy, 2009). As literature suggests, the configuration of social networks influences the resources of knowledge available by members of groups affecting to the performance (Nahapiet \& Ghoshal, 1998; Reagans \& Zuckerman, 2001; Wong, 2008; Chung \& Jackson, 2012). Empirical evidence shows a positive and significant effect of social capital dimensions on both scientific productivity and research impact (Abbasi, Altmann, \& Hossain, 2011; Gonzalez-Brambila, 2014; Gonzalez-Brambila, Veloso \& Krackhardt, 2013; Li, Liao \& Yen, 2013; Rodriguez \& Gonzalez-Brambila, 2016). Numerous studies describe how high levels of social capital associated with good ties between researchers lead to high levels of creativity and access to a greater volume of information. Therefore, if higher levels of social capital can lead researchers to have a greater number of scientific articles and to improve the quality of these articles, analysing how the social capital of the members of the research group can be built it is an increasingly important issue for academics, but also for knowledge managers and for research-based organizations.

The purpose of the article is that based on theoretical approaches and empirical evidence to establish a conceptual model on the relationship between social capital and the performance of researchers. Literature focused on social capital in the academic context is scarce. This paper tries to fill this gap and offers a conceptual model that determines the relationship between the relational, cognitive and structural social capital dimensions embedded in internal and external research networks and the researchers performance, emphasizing the connections between social capital dimensions and the processes of creation and exchange of knowledge. By means of the literature review, the paper highlights the basis of social capital construct that affects to academic research results and the mechanisms that explain how social capital is built and why it affects to researchers performance about which there is limited knowledge in the academic context.

The paper is structured as follows. Section 2 presents the theoretical arguments making a brief description of the main theoretical perspectives from which the social capital within the area of management has been addressed. Section 3 
focuses on the empirical evidence about the social capital-performance relationship. Section 4 synthetizes the main conclusions of the study as well as future research lines.

\section{Social Capital: Theoretical Background}

In order to construct the conceptual model, a thorough revision of both theoretical and empirical literature has been carried out. First, the review of the literature has focused on the works of pioneering authors such as Bourdieu, Coleman and Putnam who established the bases of social capital. This has allowed us to analyse the contributions of each one of them as well as the clarification of the concept. Second, the most influential theoretical works that have laid the foundations of social capital in the context of organizations have been reviewed. Finally, the empirical literature that focused on the relationship between social capital and results in the organizational and academic sphere has been reviewed. The review of the theoretical foundations is collected in this section, while the review of the empirical literature is presented in Section 3. Throughout these two Sections, the existing knowledge gaps about this topic are highlighted and we show our contribution to fill those gaps.

The concept of social capital began to be discussed in the scientific literature in studies carried out by Bourdieu (1985), Coleman (1988; 1990) and Putnam (1993). The first systematic study on social capital was carried out by Bourdieu (1985: 248) who defined it as "the aggregate of the actual or potential resources which are linked to possession of a durable network of more or less institutionalized relationships of mutual acquaintance and recognition —or in other words, to membership in a group". The volume of social capital of the individual depends both on the size of its network of connections, and on the volume of capital that those individuals with whom they have relationships (Bourdieu, 1985). Coleman (1988:S98) defined social capital as "a variety of different entities, with two elements in common: they all consist of some aspect of social structures, and they facilitate certain actions of actors- whether persons or corporate actors- within the structure". This broader perspective of social capital fostered the application of the term to numerous different and sometimes contradictory processes, although the author introduces some notes on its scope, considering that certain social structures perform this function of social capital generation better than others (Portes, 1998). As Granville (2009) points out, both authors, Bourdieu and Coleman, agree that social capital is inherent to social relations and that investment in interpersonal relationships is what creates social capital; however, they differ in the phenomenon to explain as in the formulation of the groups in which the social capital exists. Putnam (1993) refers to social capital as "features of social organization, such as networks, norms, and trust that facilitate coordination and cooperation for mutual benefit". Trust can thus be considered as a result of social capital or as a component of the shared values that constitute social capital or both (Woolcock, 2001; Cote \& Healy, 2001).

Social capital construct has been widely applied in the field of social sciences by numerous researchers that have led to numerous definitions (Nahapiet \& Ghoshal, 1998; Lin, 2001; Adler \& Kwon, 2002). However, the definition of social capital most used in the management and organizational literature is that carried out by Nahapiet and Ghoshal (1998) whom define social capital as "the sum of the actual and potential resources embedded within, available through, and derived from the network of relationships possessed by an individual or social unit" (Nahapiet \& Ghoshal, 1998:243). Nahapiet and Ghoshal (1998) grouped the social capital's resources in three dimensions -relational, structural and cognitive- that facilitate the creation and exchange of knowledge. The relational dimension refers to the assets such as trust, norms of cooperation, identity created though the relationship those researchers develop with each other (Nahapiet \& Ghoshal, 1998). The cognitive dimension refers to those resources that researchers develop over time with others such as beliefs, language, values and codes facilitating better understanding of common objectives (Chow \& Chan, 2008; Tsai \& Ghoshal, 1998). The structural dimension includes the patterns of connection between members in a network. The structural dimension overlaps with the social network concept (Zheng, 2010).

From a theoretical point of view, the social network theory provides two different perceptions of social capital that are particularly relevant for organizational performance, that is, structural holes and closure network approaches (Reagans \& Zuckerman, 2001). On the one hand, the structural holes approach (Burt, 1992) states that the existence of holes in the network structure is an opportunity to interconnect information flows from multiple sources that are not connected to each other, creating efficient and information-rich networks. This represents a source of advantages for the actor who acts as a bridge between these contacts since he/she is directly connected to them, but the others are only connected to each other in an indirect way allowing him/her to have access to a greater volume of information making him/her a more attractive actor for their networks of contacts (Ahuja, 2000).

According to Burt (1992), the theory of structural holes and the strength of weak ties approach are connected, describing the same phenomenon. Granovetter (1973) points out the importance of weak ties versus strong ties as a source of unique information and resources. There are two main reasons why networks with weak links are considered to provide information benefits superior to strong networks. The first is that actors with strong ties have more 
redundant and therefore less valuable information; the second is that weak ties are related to a larger network size, as it is less costly to maintain. This increases the number of structural holes and hence networks efficiency (Anderson, 2008). As Lin, Vaughn and Ensel (1981) argue, it is not the weakness of the ties themselves, which confers the advantage of the member, but through those ties it is more likely to maintain relations with someone who provides the resources that allow it achieve their objectives (Seibert, Kraimer \& Liden, 2001).

On the other hand, Coleman (1988) emphasizes that closure networks that is, networks where members are strongly connected and interact with each other favour the acquisition of a greater level of mutual trust and coordination, which will benefit performance (Reagans \& Zuckerman, 2001). Dense networks are considered a basic condition for the creation of social capital, facilitating the existence of effective norms and the reliability of social structures (Portes, 1998). Members of a dense network have the benefit of having easier access to valuable redundant information since repeated and consistent information generates more trust. Strong ties are associated with greater motivation to help, greater trust and ease of transferring information and knowledge (Gulati, 1995; Rowley, Behrens \& Krackhardt, 2000; Uzzi, 1996). The main argument of this approach is that, without trust and behavioural norms, opportunistic behaviours may arise making it difficult to share knowledge among actors (Gonzalez-Brambila, 2014).

Adler and Kwon (2002:18), based on a broad review of the literature, propose a concept of social capital centred on the organizational sphere, considering it as "the resource available to the actors according to their locations in the structure of their social relations". Social capital can be analysed from the point of view of the relationships that an actor maintains with other actors. When the actors obtain the resources of social capital from the social structures external to their focal community, social capital is called bridging social capital. If, on the other hand, social capital is considered as a resource located in the internal networks of the community, the perspective is bonding social capital. In this case, social capital is derived from the internal forces within its community where strong bonds are established between the actors that interact frequently, since they share similar interests and are familiar with each other (Andriani \& Christoforou, 2016). To explain how social capital is generated from relationships, these authors identify three sources that must be present for social capital to be generated or active: opportunity, motivation and ability (OMA model). The opportunity refers to the network of social ties of a company. Social networks, both external and internal, provide the actor with the opportunity for the transfer of social capital. Mutual trust between individuals belonging to a network is a condition for motivation in relationships mediated by social capital. Skill includes capabilities and resources that an individual can offer or obtain for participating in the creation of social capital (Mahmood, 2015). The lack of one of these three components will limit the generation of social capital, so if an actor does not have relationships or ties that link him/her with other organizations (opportunity) he/she is not motivated to contribute (motivation) or if he/she does not have a series of resources and capabilities (ability), can not be a source of social capital for the network (Mahmood, 2015).

\section{Social Capital and Performance}

The paper proposes a conceptual model of the social capital- performance relationship (Figure 1). Based on the previously review of theoretical approaches, specifically in Nahapiet and Ghoshal (1998) and Adler and Kwon (2002) models, the left part of the Figure 1 has been constructed. It expresses the foundations of social capital; the interrelated relational, cognitive and structural dimensions together with the internal and external social networks shape the social capital as valuable asses of the research groups. The right part of Figure 1 is explained in the following paragraphs.

As mentioned above, in the last decades to the traditional teaching and research missions, a third mission has joined to the activity of university, as it is the transfer of scientific and technological knowledge to society. Knowledge-based societies consider knowledge as pillar of socio-economic development.

The concept of knowledge is subject to different interpretations depending on the context in which it is used. This term has been related to others such as data, information, intelligence, skills, experiences, ideas and intuitions (Gao et al., 2008). Nonaka and Takeuchi (1995:58) give a definition at the organizational level referring to the knowledge concept as "a dynamic human process of justifying personal belief towards the truth".

In the context of knowledge-based of firm theory the processes of knowledge management and knowledge creation become relevant. Knowledge management, in a broad sense, consists of mechanisms, systems and routines implemented by organizations to ensure that the right knowledge is available to the right person at the right time (Wang, 2006). Knowledge management is considered as an important facilitator of knowledge creation (Rubenstein-Montano, Buchwalter, \& Liebowitz, 2001). The creation of knowledge, on the other hand, is the process by which new knowledge is produced (Rubenstein-Montano, Buchwalter, \& Liebowitz, 2001) or the substitution of already existing knowledge (Petland, 1995); the availability of existing knowledge being an important prerequisite for the creation of knowledge. 
Nonaka and Takeuchi (1995) point out that for understanding the theory of organizational knowledge creation it is necessary to know the knowledge nature. The process that creates knowledge in organizations is the spiral of knowledge conversion that integrates the two dimensions of knowledge, the ontological dimension -individual, group, or organizational- and the epistemological dimension -tacit and explicit knowledge-. The knowledge creation model (SECI model of knowledge dimensions) created by Nonaka and Takeuchi (1995) considers the creation of organizational knowledge as an interaction between the two types of knowledge tacit and explicit, where knowledge moves at the individual, group and organizational levels (Note 1).

The process of creating knowledge is different for academic research organizations and private companies because they have not the same objectives (Wang, Peters, \& Guan, 2006). Wang, Peters, \& Guan (2006) taking into account that the main objective of the academia is the publication of research results, proposing a knowledge creation model based on the modification of Nonaka and Takeuchi's (1995) model, including the distinction made by Krogh (1998) between individual and collective processes. In the individual processes, individuals learn and think for themselves, while collective processes involve the interaction of individuals with others, so they are influenced by both the structure and the culture of the organization.

Social capital is one of the factors that researchers have considered critical in the creation and exchange of knowledge (Nahapiet \& Ghoshal, 1998). Pinho, Rego \& Pina e Cunha (2012) point out that both internal and external social capital can act as facilitators as well as barriers of knowledge acquisition, creation, sharing and transfer knowledge processes among individuals, groups and organizations. This is especially important in the academic context where most of the research is carried out in collaboration between researchers.

Several papers have studied the relationship between the social capital embedded in research networks and research outputs at the individual level in the academic context. For example, González-Brambila (2014) analysed how the dimensions of social capital affected to the publications of the researchers. The results of her study indicated that to have a central position in the research network, the number of ties of a researcher and the extent to which it publishes with researchers from different areas of knowledge positively affected scientific productivity. Gonzalez-Brambila, Veloso and Krackhardt (2013) explored the effects of different dimensions of social capital on both publications and citations. They found that relational dimension counts for citations, while cognitive dimension was associated with increased publications. In relation to structural dimension, structural holes had a positive effect in the number of citations. Similarly, Rodriguez and Gonzalez-Brambila (2016) found a positive effect of degree and closeness centrality measures on publications and citations in the field of engineering, betweenness was significant with publications, while eigenvector had a negative effect on publications. Structural holes and density had a positive effect on publications and citations. Abbasi, Altmann, and Hossain (2011) examined the effect of social networks on the performance of researchers measured through citations. The results indicated that normalized degree of centrality, efficiency and average ties strength had a positive effect on citations. Finally, Li, Liao and Yen (2013) assessed how the social capital embedded in social network could be used to achieve greater citations. The results showed that betweenness centrality was the most influential factor affecting citations, while other factors related to relational and cognitive social capital had an indirect effect on research impact.

In summary, this paper contributes to the scarce literature on the relationship between social capital and research results in the academic field in several ways. First, the paper proposes a conceptual model that takes into consideration the dimensions of social capital from a double perspective including on the one hand, the relational, cognitive and structural dimensions of social capital (Nahapiet \& Ghoshal, 1998) and on the other hand, the internal and external dimensions (Adler \& Kwon, 2002). Most studies analyse social capital only from one perspective. Second, the model highlights the connections between the diverse dimensions of social capital and the knowledge creation and exchange processes and their effect on performance. Many studies focus on the relationship between social capital and performance, but do not take into account the processes of creation and exchange of knowledge in that relationship. 


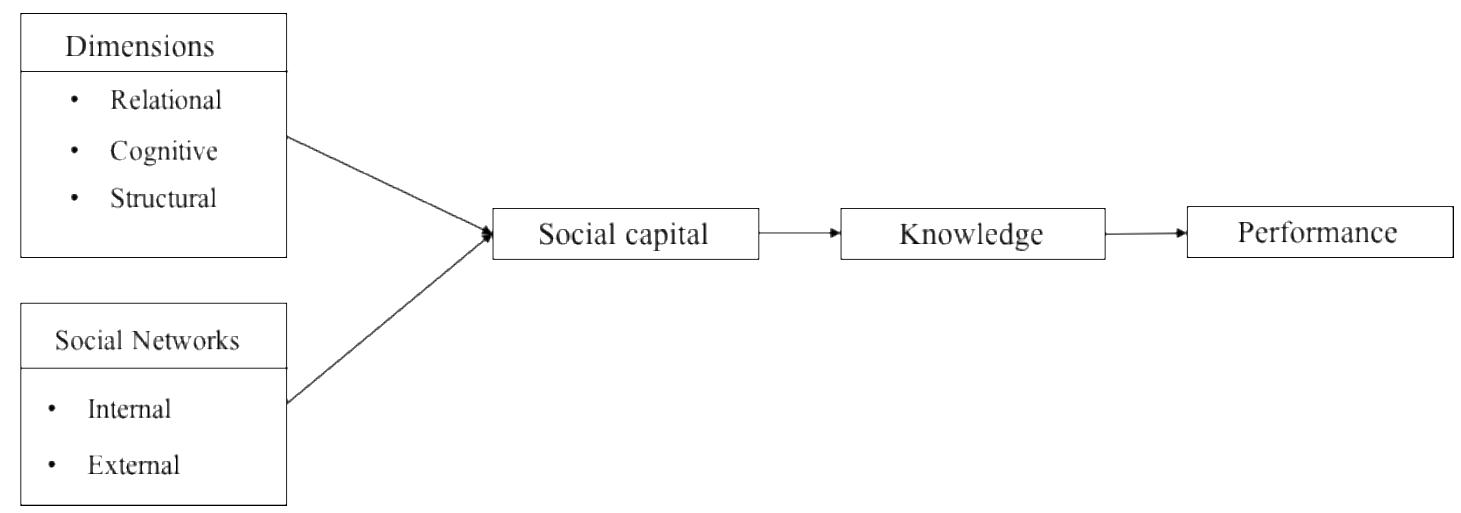

Figure 1. Social capital-performance relationship

Source: own elaboration

\section{Conclusions and Future Lines of Research}

Universities play an important role as knowledge producer in currently knowledge-based societies. A key issue is to know the causal mechanisms through which an increase in the quantity and quality of research results (publications, citation, h-index, ....) can be achieved. This paper proposes a conceptual model in which social capital embedded in internal and external social research networks is determinant of the research results shedding light on the underlying theoretical aspects that explain how the social capital of research groups is built. The paper contribute to the existing literature on this topic proposing a theoretical model in which both relational, cognitive and structural social capital and internal and external social capital are considered together for explaining social capital-performance relationship. A greater knowledge of the role of the different dimensions of social interactions in building internal and external social capital could help to improve the social capital of research groups. On the other hand, the connections between social capital dimensions and knowledge creation and knowledge sharing processes are established in the model.

The document is descriptive in nature, not prescriptive but can serve as a guide for research managers if it is to improve the social capital of research groups in a way that increases research results.

In the management literature, the social capital concept has had a wide development, mainly from the work of Nahapiet and Ghoshal (1998). These authors established a theoretical framework to analyse social capital by identifying the three different, although highly interrelated dimensions of the construct, the structural, the relational and the cognitive dimensions, which facilitate the creation and exchange of knowledge. On the other hand, Alder and Known (2002) distinguish between bridging and bonding social capital, establishing that opportunity, motivation and ability are three requisites for building social capital.

Social capital is one of the factors that literature considers critical in the creation and exchange of knowledge, affecting the collective processes of knowledge production that involve the interaction of an individual with others, so they are influenced both by the structure and by the organization culture. The empirical literature provides evidence of a positive relationship between social capital and the acquisition and exchange of information and knowledge in organizations (Anderson, 2008; Van den Hooff \& Huysman 2009; Hau et al., 2013, Chang, Hsu \& Lee, 2015, Jiang \& $\mathrm{Hu}, 2015$; Choi, 2015). Social capital is a resource available to research group that can be managed. Research managers must to stimulate social capital within the research group encouraging trust and cooperation among group members and fostering external links with other researchers and research groups increasing acquisition, creation, sharing and transfer of knowledge (Allen et al., 2007; Bruneel et al., 2010; Chang \& Li, 2007; Pinho, Rego \& Pina e Cunha, 2012; Yokaku \& Zawdie, 2010). Research managers must not only implement measures that facilitate the development of social capital but also measures that reduce the factors that create poor social capital (Pinho, Rego \& Pina e Cunha, 2012). In this way they will facilitate creation and sharing knowledge improving research performance (Curseu, Raab, Han \& Loenen, 2012; Phelps, Heidl \& Wadhwa, 2012; Tsai et al., 2014).

This is a conceptual paper. For testing and verifying the model, quantitative studies conducted in research groups and research networks are needed. This would allow identifying the enablers or obstacles of the creation and exchange of knowledge that are related to each dimension of social capital. 
As mentioned previously, in the academic context several papers have found that social capital affect positively and significantly on scientific productivity and research impact. Mostly these papers used social network analysis (SNA) techniques to evaluating the social capital dimensions (Gonzalez-Brambila, 2014; Abbasi, Altmann, \& Hossain, 2011; Rodriguez \& Gonzalez-Brambila, 2016) instead of scale instrument. However, in organizational context usually social capital is measured by a survey method (Chow \& Chan, 2008; Chua, 2002; Hau et al., 2013; Choi, 2015). Consequently, few scales are available to research managers to measure academic social capital. Science is being increasingly organized around larger research groups (Cummings \& Kiesler, 2014), it could be helpful to rely on the methods used in the organizational literature to measure and manage research group's social capital. We consider that a scale to measure social capital could be a useful instrument to highlight the underlying mechanisms that explain the building of social capital of research groups. Future research should develop a valid and reliable scale for measuring social capital in the academic world. Comparative studies measuring social capital with scale and social network analysis techniques should be carried out in order to compare the appropriateness of both methods to evaluate the effects of social capital on research results. More research in this line would be needed to better understand the dynamics of research groups and improve knowledge management processes.

\section{Acknowledgement}

Authors are ordered alphabetically. This study has benefited from financing from the Research Project ECO2014-56580-R of the Spanish Ministry of Economy and Competitively, the Research Projects P12-SEJ-1810; P12-ASEJ-1618 from the Andalusian Government (Spain) and PR2016-018 (Research Projects University of Cadiz).

\section{References}

Abbasi, A., Altmann, J., \& Hossain, L. (2011). Identifying the effects of co-authorship networks on the performance of scholars: a correlation and regression analysis of performance measures and social network analysis measures. Journal of Informetrics, 5, 594-607. https://doi.org/10.1016/j.joi.2011.05.007

Adler, P.S., \& Kwon, S. (2002). Prospects for a New Concept. The Academy of Management Review, 27(1), 17-40. https://doi.org/10.5465/amr.2002.5922314

Ahuja, G. (2000). Collaborations Networks, Structural Holes, and Innovation: A longitunal study. Administrative Science Quarterly, 45. https://doi.org/10.2307/2667105

Allen, J., James, A., \& Gamlen, P. (2007). Formal versus informal knowledge networks in R\&D: a case study using social network analysis. $R \& D$ Management, 37(3), 179-96. https://doi.org/10.1111/j.1467-9310.2007.00468.x

Anderson, M. (2008). Social networks and the cognitive motivation to realize network opportunities: a study of managers' information gathering behaviors. Journal of Organizational Behavior, 29, 51-78. https://doi.org/10.1002/job.459

Andrews, R. (2010). Organizational social capital, structure and performance. Human Relations, 63, 583-608. https://doi.org/10.1177/0018726709342931

Andriani, L., \& Christorou, A. (2016). Social Capital: A Roadmap of Theoretical and Empirical Contributions and Limitations. Journal of Economic Issues, L(1). https://doi.org/10.1080/00213624.2016.1147296

Bolander, W., Satornino, C.B., Hughes, D.E., \& Ferris, G.R. (2015). Social Networks within sales organizations: Their development and importance for salesperson performance. Journal of Marketing, 79, 1-16. https://doi.org/10.1509/jm.14.0444

Bontis, N. (1996). There's a price on your head: managing intellectual capital strategically. Business Quarterly, 60(4), 40-47.

Bourdieu, P. (1985). The forms of capital. In Richardson J.G. (Ed.), Handbook of Theory and Research for the Sociology of Education (pp. 241-258). New York, NY: Greenwood Press.

Bozeman, B., Fay, D., \& Slade, C. (2013). Research collaboration in universities and academic entrepreneurship: the-state-of-the-art. Journal Technology Transfer, 38, 1-67.

Bruneel, J., D'este, P., \& Salter, A. (2010). Investigating the factors that diminish the barriers to university-industry collaboration. Research Policy, 39(7), 858-68. https://doi.org/10.1016/j.respol.2010.03.006

Carroll, G.R., \& Teo, A.C. (1996). On the social capital of managers. Academy of Management Journal, 39, 421-440. 
Chang, C., Hsu, M., \& Lee, Y. (2015). Factors Influencing Knowledge-Sharing Behavior in Virtual Communities: A Longitudinal Investigation. Information Systems Management, 32(4), 331-340 https://doi.org/10.1080/10580530.2015.1080002

Chang, W.C. \& Li, S.T. (2007). Fostering knowledge management deployment in R\&D workspaces: a five-stage approach. $R \& D$ Management, 37(5), 479-93. https://doi.org/10.1111/j.1467-9310.2007.00484.x

Chatterton, P., \& Goddard, J. (2000). The Response of Higher Education Institutions to Regional Needs. European Journal of Education, 35(4). https://doi.org/10.1111/1467-3435.00041

Choi, Y. (2015). The impact of social capital on employees' knowledge-sharing behavior: an empirical analysis of u.s. federal agencies. Public Performance \& Management Review, 39, 381-405.

Chow, W.S., \& Chan, L.S. (2008). Social network, social trust and shared goals in organizational knowledge sharing. Information \& Management, 45, 458-465. https://doi.org/10.1016/j.im.2008.06.007

Chung, Y., \& Jackson, S. (2011). The Internal and External Networks of Knowledge-Intensive Teams: The Role of Task Routineness. Journal of Management.

Coleman, J. (1988). Social Capital in the Create of Human Capital. American Journal of Sociology, 94, 95-120. https://doi.org/10.1086/228943

Coleman, J. (1990). Foundations of social capital. Cambridge: Belknap.

Cote, S., \& Tom Healy (2001). The Well-being of Nations. The role of human and social capital. Organisation for Economic Co-operation and Development. Paris, France: OECD.

Cummings, J., \& Kiesler, S. (2014). Organization theory and the changing nature of science. Journal of Organization Design, 3, 1-16. https://doi.org/10.7146/jod.18596

Curseu, P.L., Raab, J., Han, J., \& Loenen, A. (2012). Educational diversity and group effectiveness: a social network perspective. Journal of Managerial Psychology, 27, 576-594. https://doi.org/10.1108/02683941211252437

Edvinson, L., \& Malone, M. (1997). Intellectual capital: realizing your company's true value by finding its hidden brainpower. Nueva York: Harper Business.

Etzkowitz, H., Webster, A., Gebhardt, C., \& Terra, B.R.C. (2000). The future of the university and the university of the future: evolution of ivory tower to entrepreneurial paradigm. Research Policy, 29(2), 313-330. https://doi.org/10.1016/S0048-7333(99)00069-4

Fischer, H., \& Pollock, T. (2004). Effects of social capital and power on surviving transformational change: The case of initial public offerings. Academy of Management Journal, 47, 463-481.

Gao, F., Li, M., \& Clarke, S. (2008). Knowledge, management, and knowledge management in business operations. Journal of knowledge management, 12(2), 3-17.

Gazni, A., \& Didegah, F. (2011). Investigating different types of research collaboration and citation impact: A case study of Harvard University's publications. Scientometrics, 87(2), 251-265.

Glanville, J.L., \& Bienenstock, E.J. (2009). A typology for understanding the connections among different forms of social capital. American Behavioral Scientist, 52, 1507-1530. https://doi.org/10.1177/0002764209331524

Gonzalez-Brambila, C. (2014). Social capital in academia. Scientometrics, 101, 1609-1625. https://doi.org/10.1007/s11192-014-1424-2

Granovetter, M. (1973). The strength of Weak Ties. American Journal of Sociology, 78(6), 1360-1380. https://doi.org/10.1086/225469

Gulati, R. (1995). Social Structure and Alliance Formation Patterns: A Longitudinal Analysis. Administrative Science Quartely, 40, 619-652. https://doi.org/10.2307/2393756

Hau, Y., Kim, B., Lee, H., \& Kim, Y.G. (2013). The effects of individual motivations and social capital on employees' tacit and explicit knowledge sharing intentions. International Journal of Information Management, 33, 356-366. https://doi.org/10.1016/j.ijinfomgt.2012.10.009

Huggins, R., \& Johnston, A. (2009). The economic and innovation contribution of universities: a regional perspective. Environment and Planning C: Government and Policy, 27, 1088-1106. https://doi.org/10.1068/c08125b

Jiang, Z., \& Hu, X. (2015). Knowledge Sharing and Life Satisfaction: The Roles of Colleague Relationships and Gender. Social Indicators Research, 126, 379-394. 
Katz, J., \& Martin, B. (1997). What is research collaboration?. Research Policy, 26, 1-18.

Kostova, T., \& Roth, K. (2003). Social capital in multinational corporations and a micro-macro model of its formation. Academy of Management Review, 28(2), 297-317. https://doi.org/10.5465/amr.2003.9416356

Krogh, G. (1998). Care in knowledge creation. California Management Review, 40(3), 133.

Lee, S., \& Bozeman, B. (2005). The Impact of Research Collaboration on Scientific Productivity. Social Studies of Science, 35(5), 673-702.

Leitner, K.H. (2004). Intellectual capital reporting for universities conceptual background and application for Austrian universities. Research Evaluation, 13(2), 129-140. https://doi.org/10.3152/147154404781776464

Li, E., Liao, C., \& Yen, H. (2013). Co-authorship networks and research impact: A social capital perspective. Research Policy, 42, 1515-1530.

Lin, N. (2001). Social Capital: A Theory of Social Structure and Action. Cambridge, MA: Cambridge University Press. https://doi.org/10.1017/CBO9780511815447

Lin, N., Vaughn, J., \& Ensel, W. (1981). Social resources and strength of ties: structural factors in occupational attainment. American Sociological Review, 46(4), 393-405. https://doi.org/10.2307/2095260

Mahmood, K. (2015). Social capital: from concept to theory. Pakistan Journal of Science, 67(1).

Maurer, I., \& Ebers, M. (2006). Dynamics of Social Capital and Their Performance Implications: Lessons from Biotechnology Start-ups. Administrative Science Quarterly, 51, 262-292.

Nahapiet, J., \& Ghoshal, S. (1998). Social capital, intellectual capital, and the organizational advantage. Academy of Management Review, 23(2), 242-266. https://doi.org/10.5465/amr.1998.533225

Nonaka, I., \& Takeuchi, H. (1995). The Knowledge-Creating Company: How Japanese Companies Create the Dynamics of Innovation. Oxford University Press, Oxford.

Park, S., \& Luo, Y. (2001). Guanxi and organizational dynamics: organizational networking in chinese firms. Strategic Management Journal, 22, 455-477.

Parker, G.M. (2003). Cross-functional teams: Working with allies, enemies, and other strangers. John Wiley \& Sons.

Pentland, B.T. (1995). Information Systems and Organizational Learning: The Social Epistemology of Organizational Knowledge Systems. Accounting, Management and Information Technologies, 5(1), 1-21.

Phelps, C., Heidl, R., \& Wadhwa, A. (2012). Knowledge, networks, and knowledge networks: a review and research agenda. Journal of Management, 38, 1115-1166. https://doi.org/10.1177/0149206311432640

Pinho, I., Rego, A., \& Cunha, M. (2012). Improving Knowledge Management Processes: A Hybrid Positive Approach. Journal of Knowledge Management, 16(2), 215-242. https://doi.org/10.1108/13673271211218834

Portes, A. (1998). Social Capital: its Origins and Applications in Modern Sociology. Annual Review of Sociology, 24, 1-24. https://doi.org/10.1146/annurev.soc.24.1.1

Putnam, R. (1993). The Prosperous Community: Social Capital and Public Life. The America Prospect, 13, 35-42.

Reagans, R., Zuckerman, E.W., \& McEvily, B. (2001). Networks, diversity, and productivity: the social capital of corporate R\&D teams. Organization Science, 12(4), 502. https://doi.org/10.1287/orsc.12.4.502.10637

Rodan, S. (2010). Structural holes and managerial performance: Identifying the underlying mechanisms. Social Networks, 32, 168-179. https://doi.org/10.1016/j.socnet.2009.11.002

Rostila, M. (2010). The facets of social capital. Journal for the Theory of Social Behaviour, 41(3), 308-326. https://doi.org/10.1111/j.1468-5914.2010.00454.x

Rothaermel, F.T., Agung, S.D., \& Jiang, L. (2007). University entrepreneurship: a taxonomy of the literature. Industrial and Corporate Change, 16(4), 691-791. https://doi.org/10.1093/icc/dtm023

Rowley, T., Behrens, D., \& Krackhardt, D. (2000). Redundant governance structures: An analysis of structural and relational embeddeness in the steel and semiconductor industries. Strategic Management Journal, 21, 369-386. https://doi.org/10.1002/(SICI)1097-0266(200003)21:3<369::AID-SMJ93>3.0.CO;2-M

Rodriguez, J., \& Gonzalez, B. (2016). The effects of external collaboration on research output in engineering. Scientometrics, 109, 661-675. 
Rubenstein-Montano, B., Buchwalter, J., \& Liebowitz, J. (2001). Knowledge management: a US Social Security Administration case study. Government Information Quarterly, 18.

Sanchez, M., Elena, S., \& Castrillo, R. (2009). Intellectual capital dynamics in universities: a reporting model. Journal of Intellectual Capital, 10(2), 307-324. https://doi.org/10.1108/14691930910952687

Seibert, S., Kraimer, M., \& Liden, R. (2001). A social capital theory of career success. Academy of Management Journal, 44(2), 219-237.

Sooryamoorthy, R. (2009). Do types of collaboration change citation? Collaboration and citation patterns of South African science publications. Scientometrics, 81(1), 177-193.

Steward, T. (1997). Intellectual Capital: The Wealth of Organizations. New York: Doubleday.

Tsai, F.S., Baugh, G.S., Fang, S.C., \& Lin, J.L. (2014). Contingent contingency: knowledge heterogeneity and new product development performance revisited. Asia Pacific Journal of Management, 31, 149-169. https://doi.org/10.1007/s10490-013-9355-7

Tsai, W., \& Ghoshal, S. (1998). Social capital and value creation: the role of intrafirm networks. Academy of Management Journal, 41(4), 464.

Uzzi, B. (1996). Embeddedness and economic performance: the network effect. American Sociological Review, 61, 674-698. https://doi.org/10.2307/2096399

Van den Hoff, B., \& Huysman, M. (2009). Managing knowledge sharing: Emergent and engineering approaches. Information \& Management, 46, 1-8. https://doi.org/10.1016/j.im.2008.09.002

Wang, J., Peters, H., \& Guan, J. (2006). Factors influencing knowledge productivity in German research groups: lessons for developing countries. Journal of knowledge management, 10(4), 113-126.

Villena, V.H., Revilla, E., \& Choi, T.Y. (2011). The dark side of buyer-supplier relationships: a social capital perspective. Journal of Operations Management, 29, 561-576.

Wong, S.S. (2008). Task knowledge overlap and knowledge variety: the role of advice network structures and impact on group effectiveness. Journal of Organizational Behavior, 29, 591-614.

Woolcock, M. (2001). The place of social capital in Understanding Social and Economic Outcomes. Canadian Journal of Policy Research, 2(1), 11-17.

Xiao, Z., \& Tsui, A.S. (2007). When brokers may not work: The cultural contingency of social capital in Chinese high-tech firms. Administrative Science Quarterly, 52, 1-31. https://doi.org/10.2189/asqu.52.1.1

Yiu, D., \& Lau, C.M. (2008). Corporate entrepreneurship as resource capital configuration in emerging market firms. Entrepreneurship: Theory \& Practice, 32, 37-57. https://doi.org/10.1111/j.1540-6520.2007.00215.x

Yokakul, N., \& Zawdie, G. (2010). Innovation network and technological capability development in the Thai SME sector: the case of the Thai dessert industry. International Journal of Technology Management and Sustainable Development, 9(1), 19-36. https://doi.org/10.1386/tmsd.9.1.19_1

Youndt, M., Subramaniam, M., \& Snell, S. (2004). Intellectual Capital Profiles: An Examination of Investments and Returns. Journal of Management Studies, 41(2).

Zheng, W. (2010). A Social Capital Perspective of Innovation from Individuals to Nations: Where is Empirical Literature Directing Us?. International Journal of Management Reviews, 151-183. https://doi.org/10.1111/j.1468-2370.2008.00247.x

\section{Note}

Note 1. The SECI model contemplates four dimensions of knowledge conversion -socialization, externalization, combination, and internalization (Nonaka \& Takeuchi, 1995). 